\title{
Individual Counselling: The Experience of School Career Counsellors in Latvia
}

\author{
Rita Burceva \\ Rezekne Academy of Technologies
}

\begin{abstract}
.
Individual career counselling to pupils is an essential part of the school career counsellor's professional activity. The purpose of the research was to establish the experience of school career counsellors in terms of various aspects of practical implementation of individual counselling to pupils. The research methods: analysis of theoretical literature, an anonymous written questionnaire survey followed by data visualisation and analysis. The experience of school career counsellors on various practical aspects of individual counselling for pupils gives rise to the conclusion on the improvement of organisational aspects of counselling.

Individual career counselling sessions usually take place initiated by a pupil, and it means that the role of a school career counsellor in the school environment is clear; pupils have had a positive initial experience with the specialist. This trend demonstrates that pupils are willing to turn to a career counsellor on their own without getting other adults involved in order to deal with their career development related issues, and it also shows the practical application of the basic skills of career management. It can be concluded contextually following the results of the questionnaire survey that school career counsellors possess a good professional understanding of the organisational aspects of individual career counselling, they have a critical attitude towards the lack of resources, and in their practical work they follow the methodical and ethical principles of career counselling. A tenth of schools require improvements to their physical environment in order to allow a school career counsellor to provide professional individual career counselling sessions. It means that school career counsellors must bring up this issue with the school's management and local council, taking a proactive position for the benefit of their pupils' interests.
\end{abstract}

Keywords: career counselling; initiators of individual career counselling sessions; organisational aspects; physical environment

\section{Introduction}

The developing career counselling system, which is implemented at general secondary and vocational education institutions step by step during the recent years, fits in the modern trends of the European education policy organically. The duties of Latvian school career counsellors are performed by qualified personnel - persons, who have a higher pedagogical education, have a certificate entitling them to do this job or a professional master's degree of education with the qualification of Career Counsellor. 
The State Education Development Agency (SEDA) is the authority responsible for the provision of access to career counselling for pupils in Latvia. According to its data, in the study year 2019/ 2020 there were 369 school career counsellors employed at schools. There are about 150000 pupils at the education institutions that employ these career counsellors.

Individual career counselling to pupils is an essential part of the school career counsellor's professional activity. During the counselling sessions a school career counsellor creates conditions when at the end of a certain stage of education process following the completion of basic or secondary education pupils can take informed decisions on their future path, level of further education and choose the most suitable profession. A career counsellor can explain the current trends on the labour market, the most rational ways to present themselves to a potential employer. Conducting individual career counselling a school career counsellor can improve the young persons' ability to make justified decisions and can reduce the various barriers disturbing the decision making process: the fear of taking risks, avoiding responsibility, the young person's internal conflict between the potential creativity and the unwillingness to leave the normal comfort zone, the lack of understanding how to match the career aspirations with real opportunities. Sometimes young people lack a positive attitude towards researching and planning the career related questions, they do not possess credible information on the available professions and they lack the understanding of their skills in various sectors, as well as they have not developed the career decision making skills (Niles \& Harris-Bowlsbey, 2002). Having analysed the reasons why pupils sometimes choose an unsuitable profession, the psychologist R. Orska is of a similar opinion: the lack of knowledge on the diversity of available professions, the insufficient awareness of their skills and psychological features, the knowledge deficit in their professional identity (Orska, 2007).

Conducting further research on the difficulties of taking career related decisions, I.Gati and N.Levin identified the following additional determining factors - a very large number of job opportunities and study offers, the financial situation of a family, imagined and actual social barriers, the fear of the seriousness of this decision and the anxiety about taking the "wrong' decision (Gati \& Levin, 2014). At this age young people lack understanding that constant changes are a normal element of life. A school career counsellor can help a young person to solve a vast majority of the identified factors at an individual career counselling session and can help to evaluate together with the pupil the importance of each factor in the specific decision taking situation.

There are some studies on the philosophy, conditions of career counselling, the aims of individual career counselling sessions, the requirements for internal organisation and professional conduct, the career counselling models, the pupils' readiness to take career decisions, etc. in the theoretical literature. At the same time it is important to obtain data and to research how the implementation of the career support system is actually conducted in the initial stage, and what the actual experience of school career counsellors is in order to draw conclusions regarding the difficulties, specific circumstances that can be influenced at the level of school management or the national policy to deepen the understanding of the necessary improvements among the parties involved (school career counsellors, school management and education experts). It would enable the development of purposeful individual career counselling sessions aimed at satisfying the pupil's needs, taking into consideration the optimum physical environment and organisational aspects and bringing these sessions closer to the highest standard of service. 


\section{2nd World Conference on Research in TEACHING and EDUCATION}

\section{Methods}

The purpose of the research was to establish the experience of school career counsellors in terms of various aspects of practical implementation of individual counselling to pupils. The quantitative research took place during the second half of 2019 and 36 school career counsellors from different primary and secondary schools in Latvia agreed to take part in it. A pilot study was conducted because the selection of respondents was not representative in this case but the results were indicative of the general trends in the field of individual counselling at schools in Latvia.

The research method was an anonymous written questionnaire survey followed by data visualisation and analysis. The author of the research uses the quotes on the specific career counselling related matters expressed by researchers in the theoretical literature for the purpose of the interpretation of descriptive statistics, along with the information obtained through the process of unstructured observation, visiting more than 150 schools in Latvia and getting to know the work of school career counsellors in person and discussing their daily work activities during the time period between 2017 and 2019.

\section{Results and discussion}

During the process of the research all questionnaires were completely correctly, therefore they were all good for processing and analysis of the results.

The respondents' experience as school career counsellors differs and the obtain data reflect the present reality in Latvian schools in its entirety (see Fig.1).

Figure 1: Work experience of school career counsellors

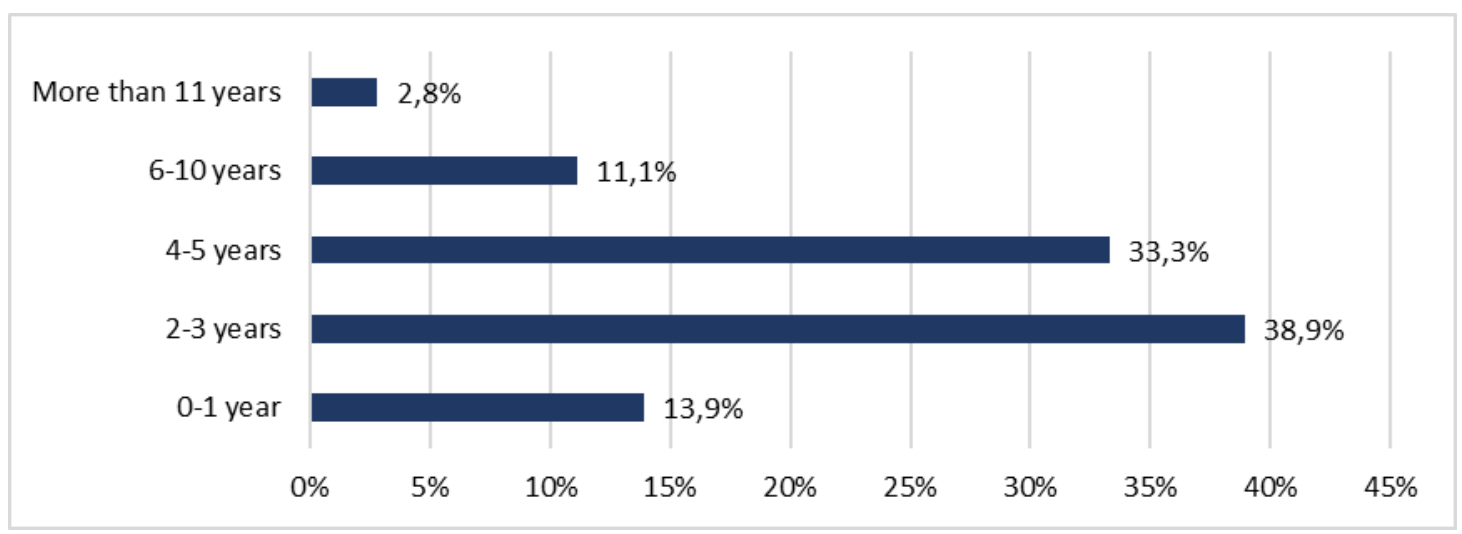

It must be taken into account that the staff turnover is a normal phenomenon on the labour market and it depends on several factors (the content and duties of work, wage, matching skills, team alchemy, the necessity to go on maternity leave or retire, a variable demand pattern for particular specialists, etc).

The workload of respondents also differs from one employer to another (see Fig.2). 
Figure 2: Workload of respondents

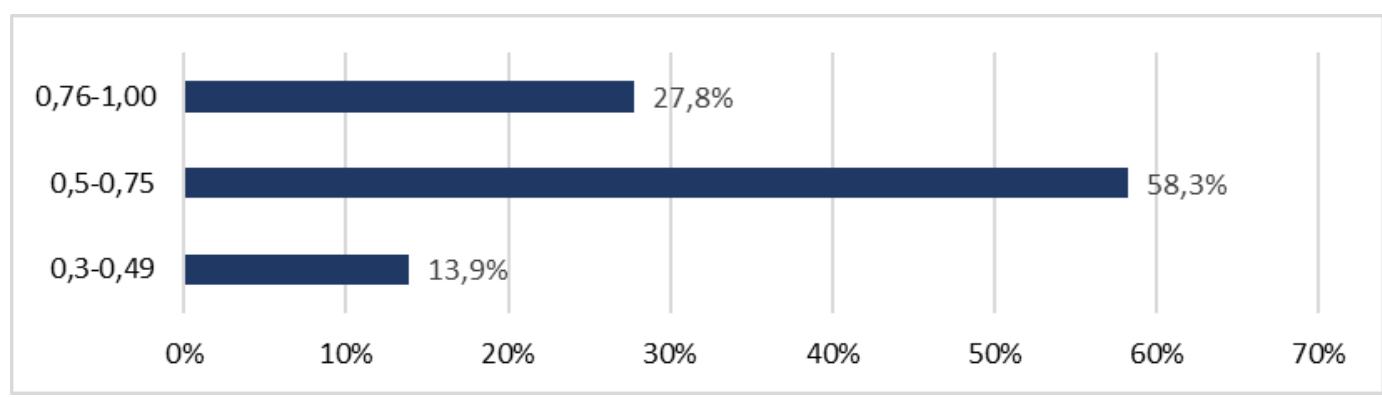

In Latvia a fulltime workload of a school career counsellor, who works with 700 pupils, is 40 working hours per week. The collected data illustrates situation that for $86.1 \%$ respondents the amount of workload is more than a half of the fulltime workload, for others it is smaller. It means that these persons have to do other duties at the same education institution or in another organisation, and it is the indication of a complicated situation. On the one hand, additional duties broaden the school career counsellors' horizon, they create preconditions for networking and the use of the new contacts for the purpose of counselling, and they also facilitate to the development of new skills, thus increasing their competitive edge. On the other hand, this situation can also cause problems, such as the necessity to divide their attention between different duties, so their concentration may suffer, their empathy during individual counselling sessions may weaken, the development of the professional identity of a school career counsellor, which is an important condition for the provision of quality of the career counselling service, may slow down.

There were some empirical data collected on the average frequency of individual career counselling sessions in the work of school career counsellors during the course of the research (see Table 1). The respondents were asked to evaluate their individual counselling experience in this aspect.

Table 1: Frequency of Individual Career Counselling Sessions

\begin{tabular}{|c|c|c|c|c|c|c|c|c|c|c|}
\hline \multirow{2}{*}{$\begin{array}{c}\text { Duty of } \\
\text { school } \\
\text { career } \\
\text { counsellor }\end{array}$} & \multicolumn{2}{|c|}{ Once a year } & \multicolumn{2}{|c|}{$\begin{array}{c}\text { At least once a } \\
\text { month }\end{array}$} & \multicolumn{2}{|c|}{$\begin{array}{c}\text { At least once a } \\
\text { week }\end{array}$} & \multicolumn{2}{|c|}{ Every day } & \multicolumn{2}{|c|}{ Never } \\
\hline & $\begin{array}{l}\text { Number } \\
\text { of } \\
\text { answers }\end{array}$ & $\%$ & $\begin{array}{l}\text { Number } \\
\text { of } \\
\text { answers }\end{array}$ & $\%$ & $\begin{array}{l}\text { Number } \\
\text { of } \\
\text { answers }\end{array}$ & $\%$ & $\begin{array}{l}\text { Number } \\
\text { of } \\
\text { answers }\end{array}$ & $\%$ & $\begin{array}{l}\text { Number } \\
\text { of } \\
\text { answers }\end{array}$ & $\%$ \\
\hline $\begin{array}{l}\text { Individual } \\
\text { career } \\
\text { counselling } \\
\text { sessions to } \\
\text { pupils }\end{array}$ & - & - & 9 & 25.0 & 23 & 63.9 & 3 & 8.3 & 1 & 2.8 \\
\hline
\end{tabular}

The demand for individual career counselling sessions at different education institutions can differ, and there are various conditions that have an effect on it. If a school career counsellor is an expert of his field, he will feel confident in using a wide range of counselling methods, and he will have accumulated substantial counselling experience, the information on the availability of career counselling sessions will be disseminated among the pupils and their parents through all possible channels (it is publicly available on information boards, on the school's homepage, it is included in all correspondence with pupils and their parents), if that is the case career counselling sessions will take place more frequently and 
they will be more accessible to children at their place of study. Pupils have more trust in career counsellors and they take an opportunity to have a talk with a specialist more if their previous experience of cooperation has been positive, for example, during the doors open days on further education opportunities, in competitions and other events on professions, economic sectors and the labour market projections, in group counselling sessions and workshops on the formulation of career goals and other career management skills. The personal initiative and motivation to get involved in the counselling process adds more value to the counselling session and its result.

It was established by the answers to a separate question posed, who the most frequent initiators of individual career counselling sessions were at school. The obtained data were arranged in the table according to the evaluation provided by the school career counsellors (see Table 2).

Table 2: Initiators of Individual Career Counselling Sessions

\begin{tabular}{|c|l|c|}
\hline No. & \multicolumn{1}{|c|}{ Initiator } & Place \\
\hline 1. & Pupil & 1 \\
\hline 2. & Class teacher & 2 \\
\hline 3. & Pupil's parents & 3 \\
\hline 4. & School career counsellor & 4 \\
\hline 5. & Pupil's classmates & 5 \\
\hline 6. & Subject teacher & 6 \\
\hline 7. & School's support personnel & 7 \\
\hline 8. & School's management & 8 \\
\hline
\end{tabular}

The place in Table 2 indicates the level of significance of the answer, the higher the place in the table, the more significant is the variant of the answer. The points represent the total number of places for the relevant variant of answers chosen by all respondents. The most important variant is the one with the smallest number of points. The collected research data indicate that in the absolute majority of cases a pupil will turn to a school career counsellor alone for the purpose of arranging a professional individual counselling session on the matter of his interest.

Theorists show that teachers or counsellors themselves, who care about the development of their pupils, are the primary initiators of school counselling sessions (Hornby, Atkinson, 2004). If the counselling is done by the career counsellor's initiative or that of the people who are significant to the pupil (teachers, parents, friends, etc.), but the pupil's current situation does not create cognitive dissonance or emotional discomfort to him, the pupil is less motivated to participate in the counselling session. Therefore, such a counselling session may not produce the expected result. Whereas, a self-motivated pupil may take an opportunity to use the benefit of an individual counselling session several times, for example, when the pupil's career plan, programme is in the process of development and the support of the career counsellor is required during the course of its implementation.

School career counsellors can have diverse clients in the environment of schools. The respondents' answers to the question regarding the persons who are in the need of career counselling most frequently are summarised in Table 3. 
Table 3: The Need of Career Counselling

\begin{tabular}{|c|l|c|}
\hline No. & \multicolumn{1}{|c|}{ Clients } & Place \\
\hline 1. & Pupil & 1 \\
\hline 2. & Two or more pupils together & 2 \\
\hline 3. & Pupil together with his/ her family & 3 \\
\hline
\end{tabular}

The data arranging technique used is similar to that of the previous question. In this case we can establish that most frequently pupils take an advantage of an individual career counselling session alone. Interestingly, a career counselling session together with parents is neither the first, not the second choice of a pupil, but they prefer going to a school career counsellor together with one or several classmates. There may be different interpretations for this fact. It can be the need for feeling safer when accompanied by a trustworthy classmate because career counselling is a completely new and alarming experience to some pupils. It can also be the pupil's desire to use career counselling as an opportunity for socialising, but this can only be done during the phase of developing relationships to make further counselling sessions more efficient. But we can only reason that career counselling is really needed when the client cannot solve an actual problem in his life or a problem he will likely face in the future with all his currently available resources (attitudes, knowledge, skills, material and social resources). The task of counselling is to help a client find individual, social and cultural resources that can prove useful to them in tackling current and other issues (McLeod \& McLeod, 2011). Counselling also takes place in between interviews, when, if necessary, a young person completes personal assignments on his way to the set objective as agreed with the career counsellor (Steven, 2019).

Unfortunately, the fact that the pupil's family or a pupil together with his/ her family takes part in the process of career counselling the least frequently is the sign of the relative passivity of parents. Such counselling sessions usually require more time because there are two or more opinions presented at the same time. From the point of view of career counselling, a counsellor must be able to listen empathically, clarify and interpret opinions, establish the client's strong sides in every given situation, provide feedback and reach an agreement on the future activities (Ivey, Ivey, \& Zalaquett, 2010; Ertelts \& Sulcs, 2008). The interpersonal relationship organised in this way helps to maintain a positive format for the counselling session with people, helps to start and to keep a positive attitude and to terminate unconstructive relationships as the school career counsellor's Code of Ethics and Professional Conduct requires. A school career counsellor represents all members of his trade in their entirety, and a culture of communication is one of the highest standards of professionalism (Corey \& Schneider, 1989). Whereas, the direct, honest and open approach of a counsellor helps pupils and parents to join in the process of counselling effortlessly (Bor, et al., 2002).

The organisational aspects play a crucial role in the success of a counselling session. Usually counselling interviews take place in the counsellor's office or in another room chosen by the counsellor where the process can take place undisturbed (McLeod, 2013). The attitude of school career counsellors towards maintaining confidentiality and the role of equipment in the provision of a comprehensive counselling session are shown in the answers to the final question (see Fig.3). The results show that there is only one respondent who does not provide individual career counselling sessions to pupils because there are no suitable rooms and equipment at the school, and two respondents have admitted that the physical environment and equipment are only partially suitable for the needs of professional counselling. It means 
that in approximately $9 \%$ cases it is still necessary to improve the physical environment for the purpose of providing quality counselling sessions.

Figure 3: Respondents' opinion on the suitability of rooms and equipment for individual career counselling sessions

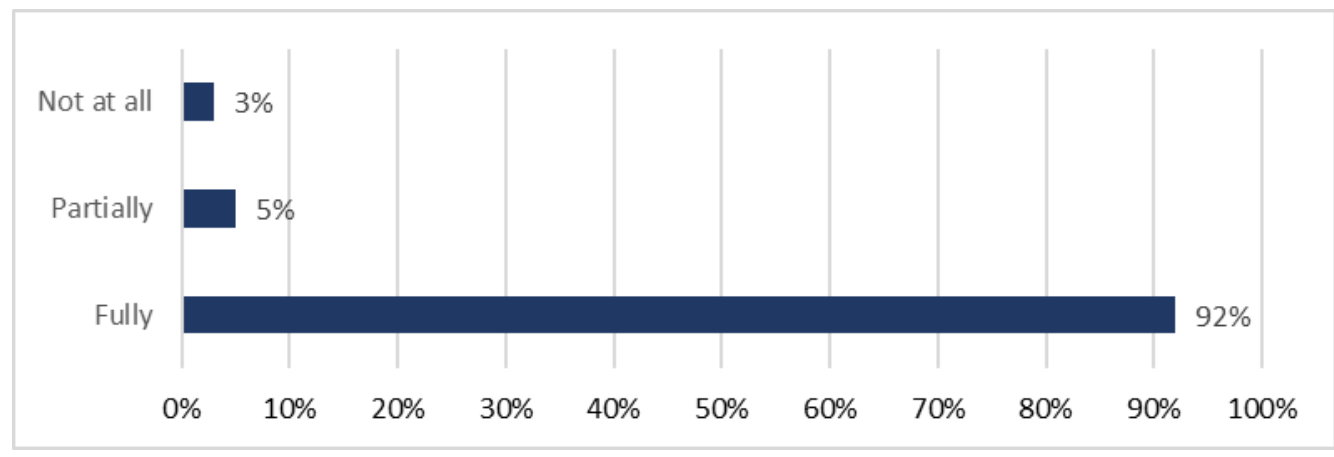

The conditions of physical environment to a large extent determine how deeply a school career counsellor can activate the pupils' self-examination, self-realisation and facilitate to the setting of goals for the future according to the personal motivation, attitudes and values of life. During the process of counselling a school career counsellor also informs and educates his clients through the use of the compilation of education opportunity resources, counselling methods and modern digital technologies. Such a style of counselling brings different personalities together, contributes to the pupils' willingness to participate and to act proactively. This proposition is also based on the researchers' realisation that nowadays it is essential to master the career self-management and study skills in the changing situations at all stages of life and career development (Hirschi, \& Läge, 2007; Smith, 2014).

\section{Conclusion (TNR 14pt., bold)}

Individual career counselling sessions for pupils is one of the main duties of a school career counsellor in his professional activity. During the course of counselling a school career counsellor creates conditions when pupils can make informed decisions on the type, level of their future education and choose the most suitable profession, when they develop their planning and career management skills, tackle real and imaginary problems that prevent them from reaching their goal. The experience of school career counsellors on various practical aspects of individual counselling for pupils gives rise to the conclusion on the improvement of organisational aspects of counselling.

Individual career counselling sessions usually take place initiated by a pupil, and it means that the role of a school career counsellor in the school environment is clear; pupils have had a positive initial experience with the specialist. This trend demonstrates that pupils are willing to turn to a career counsellor on their own without getting other adults involved in order to deal with their career development related issues, and it also shows the practical application of the basic skills of career management. It can be concluded contextually following the results of the questionnaire survey that school career counsellors possess a good professional understanding of the organisational aspects of individual career counselling, they have a critical attitude towards the lack of resources, and in their practical work they follow the methodical and ethical principles of career counselling. 


\section{2nd World Conference on Research in TEACHING and EDUCATION}

\section{$25 \_27$ September, 2020 \\ Berlin, Germany}

A tenth of schools require improvements to their physical environment in order to allow a school career counsellor to provide professional individual career counselling sessions. It means that school career counsellors must bring up this issue with the school's management and local council, taking a proactive position for the benefit of their pupils' interests.

Further studies may be needed for the evaluation and analysis of professional individual counselling skills of school career counsellors, the analysis of the themes of career counselling, a study of the pupils' needs and the use of digital tools in individual career counselling sessions.

\section{References}

[1] Bor, R., Ebner-Landy, J., Gill, S., \& Brace, C. (2002). Counselling in Schools. London: SAGE Publications Ltd.

[2] Corey \& Schneider, (1989). Becoming a Helper. Brooks/Cole Publishing Company, Pacific Grove, CA.

[3] Gati, I., \& Levin, N. (2014). Counselling for Career Decision-Making Difficulties: Measures and Methods. The Career Development Quarterly, 62.

[4] Ertelts, B. J., \& Šulcs, V. (2008). Karjeras konsultēšanas kompetences. Rīga: VIAA.

[5] Hirschi, A., \& Läge, D. (2007). The Relation of Secondary Student's Career Choice Readiness to a Six-Phase Model of Career Decision-Making. Journal of Career Development, 32(2), pp. 164-191.

[6] Hornby, Atkinson, (2004). A Framework for Promoting Mental Health in School. Pastoral Care in Education. Vol. 21, Issue 2, pp. 3-9.

[7] Ivey, A. E., Ivey, M. B., \& Zalaquett, C. P. (2018). Intentional Interviewing and Counseling: Facilitating Client Development in a Multicultural Society (9 ed.). Boston: Cengage Learning.

[8] McLeod, J., \& McLeod, J. (2011). Counselling Skills: A Practical Guide for Counsellors and Helping Professionals (2 ed.). Maidenhead: McGraw-Hill Education.

[9] McLeod, J. (2013). An Introduction to Counselling (5 ed.). New York: McGraw-Hill Education.

[10] Niles, G. S., \& Harris-Bowlsbey, J. (2002). Career Development Interventions in the 21 st Century. New Jersey: Pearson Education, pp. 458.

[11] Orska, R. (2007). Profesionālās karjeras starta apstākḷ izvēle pēc obligāatās izglītības ieguves [Selection of Career Start Conditions after Compulsory Education]. Sabiedrība, Integrācija, Izglītība. Rēzekne: RA, 238-244 lpp.

[12] Steven, J. C. (2019). Pattern of Sessions. Retrieved from Basic Counseling Skills: https://www.basic-counseling-skills.com/pattern-of-sessions.html 